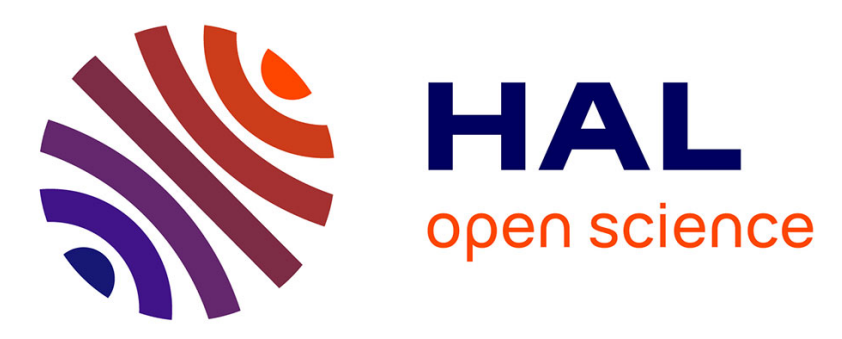

\title{
A list of methods to detect arthropod quarantine pests in Europe
}

\author{
Sylvie Augustin, William Jan de Kogel, Pierre Donner, Massimo Faccoli, \\ David Lees, Lorenzo Marini, Nicola Mori, Edoardo Petrucco Toffolo, Serge \\ Quilici, Alain Roques, et al.
}

\section{To cite this version:}

Sylvie Augustin, William Jan de Kogel, Pierre Donner, Massimo Faccoli, David Lees, et al.. A list of methods to detect arthropod quarantine pests in Europe. EPPO Bulletin, 2012, 42 (1), pp.93-94. 10.1111/j.1365-2338.2011.02523.x . hal-01190252

\section{HAL Id: hal-01190252 \\ https://hal.science/hal-01190252}

Submitted on 1 Sep 2015

HAL is a multi-disciplinary open access archive for the deposit and dissemination of scientific research documents, whether they are published or not. The documents may come from teaching and research institutions in France or abroad, or from public or private research centers.
L'archive ouverte pluridisciplinaire HAL, est destinée au dépôt et à la diffusion de documents scientifiques de niveau recherche, publiés ou non, émanant des établissements d'enseignement et de recherche français ou étrangers, des laboratoires publics ou privés. 


\title{
A list of methods to detect arthropod quarantine pests in Europe*
}

\author{
S. Augustin¹, W. J. De Kogel2, P. Donner ${ }^{3}$, M. Faccoli4, D. C. Lees ${ }^{1}$, L. Marini ${ }^{4}$, N. Mori4 \\ E. P. Toffolo ${ }^{4}$, S. Quilici ${ }^{3}$, A. Roques ${ }^{1}$, A. Yart ${ }^{1}$ and A. Battisti ${ }^{4}$ \\ IINRA, UR0633 Zoologie Forestière, CS 400001 Ardon 45075 Orléans Cedex 2 (France) \\ ${ }^{2}$ Plant Research International B.V., Wageningen UR, PO Box 69 6700, AB Wageningen (Netherlands) \\ ${ }^{3}$ CIRAD Réunion, UMR PVBMT CIRAD/Université de La Réunion, Pôle de Protection des Plantes, 7 chemin de l'IRAT, 97410 Saint-Pierre \\ (France) \\ ${ }^{4}$ Universita di Padova, DAFNAE-Entomologia, Agripolis, Viale dell'Universita 16, 35020 Legnaro (Italy); e-mail: andrea.battisti@unipd.it
}

\begin{abstract}
A total of 177 species of quarantine arthropods in Europe have been analysed for detection methods that are used in surveillance. This paper provides a link to a list where the methods most frequently used, either alone or in combination, are given for each species. Inspection remains the most common method of detection (108 species). Volatile compounds produced by either insects or host plants, or those released from food attractants are used for 85 species, while light trapping accounts for 28 species. Semiochemicals are known for 73 species, but are commercially available for only 43 species.
\end{abstract}

Detection methods are the first tools used by national plant protection organizations (NPPOs) and inspection services to find incursions of quarantine pests to implement Council Directive 2000/29/EC of 8 May 2000. The directive currently lists some 291 organisms (viruses and virus-like organisms, bacteria, fungi, insects, mites, nematodes and parasitic plants) and 'concerns protective measures against introduction into the Community of organisms harmful to plants or plant products and against their spread within the Community'. In addition, the European and Mediterranean Plant Protection Organization (EPPO) includes in its A1, A2 and Alert lists the organisms recommended for regulation as quarantine pests.

This work reviews the information available in scientific journals and other sources on the detection of arthropod quarantine pests. In addition to the information already available to each author, searches in databases (e.g. Web of Science, Scopus, CAB Abstracts) were carried out using specific terms in combination (e.g. 'surveillance' and 'detection' and 'organism name' and 'quarantine').

The most important species from Council Directive and EPPO lists were considered, based on the level of impact and interest for NPPOs and the availability of specific information in the literature, for a total of 177 species. Thus $73 \%$ of the arthropod pests listed in the Directive 2009/29 and 85\% of those in the EPPO list were covered.

The critical analysis of detection methods was carried out taking account of best practice criteria based on present knowledge. Unfortunately, for some groups, the information available is scarce and insufficient to supply the reader with the best methods to choose for the surveillance of quarantine species. Some of these are under development in other EU projects, such as

*This paper is an outcome of PRATIQUE (Enhancements of Pest Risk Analysis Techniques) a research project funded by the European Union under its 7th Framework Programme.
Q-DETECT (developing quarantine pest detection methods for use by NPPOs and inspection services) and QBOL (developing a new diagnostic tool using DNA barcoding to identify quarantine organisms in support of plant health), and in the European Food Safety Authority (EFSA) project PERSEUS (Plant health surveys for the EU territory.

Table 1 provides a summary of the methods used most frequently, either alone or in combination. Inspection remains the most common method of detection (108 species) and is generally used with an approach tailored to specific groups of arthropods. Volatile compounds produced by either insects, host plants or food attractants are used for 85 species, while light trapping accounts for 28 species. Semiochemicals are known at genus level for 104 cases and at species level for 73 species. Commercial lures are available for 43 species.

\section{Acknowledgements}

This work was done within the PRATIQUE project (Enhancements of Pest Risk Analysis Techniques) financed through the EU Seventh Research Framework Program (FP7) (contract no. 212459).

Table 1 Detection methods used

\begin{tabular}{lcc}
\hline Method & $\begin{array}{l}\text { Number } \\
\text { of species }\end{array}$ & $\begin{array}{l}\text { Number of species } \\
\text { with combined use }\end{array}$ \\
\hline Food attractant & 14 & 2 \\
Inspection & 110 & 31 \\
Light & 28 & 28 \\
Para-pheromone & 7 & 0 \\
Pheromone & 50 & 22 \\
Plant odour & 20 & 5 \\
\hline
\end{tabular}




\section{Une liste of méthodes pour détecter des arthropodes de quarantaine en Europe}

Un ensemble de 177 espèces d'arthropodes de quarantaine en Europe ont été analysés pour identifier les méthodes de détection qui sont utilisées pour leur surveillance. Cet article fournit un lien vers une liste qui donne les méthodes les plus fréquemment utilisées, seules ou en combinaison, pour chaque espèce. L'inspection reste la méthode la plus fréquente de detection (108 espèces). Les composées volatiles produits soit par des insectes, soit par les plantes-hôtes ou libérés par des aliments, sont utilisés pour 85 espèces, alors que les pièges lumineux sont utilisés pour 28 espèces. Les substances semiochimiques sont connues pour 73 espèces, mais ne sont disponibles commercialement que pour 43 espèces.

\section{Перечень методов, позволяющих выявлять членистоногие карантинные вредные организмы в Европе}

По методам выявления, которые используются при надзоре, было проанализировано в общей сложности 177 видов карантинных членистоногих в Европе. В статье дается адрес перечня, в котором для каждого вида карантинных членистоногих указаны наиболее часто используемые методы, либо самостоятельно, либо в их сочетании. При этом обследования остаются наиболее распространенным методом обнаружения (для 108 видов). Волатильные соединения, испускаемые либо насекомыми, либо растениями-хозяевами, либо пищей, используются для 85 видов, в то время как отлов в световые ловушки применяется для 28 видов. Семиохимикаты применяются для 73 видов, однако в торговой сети они доступны только для 43 видов.

\section{References}

The complete list of species and relevant methods can be consulted at http://archives.eppo.int/files/pratique_42_1/augustin.xls

The reference list will be included in a more extensive review expected to be published subsequently in EPPO Bulletin. 